\title{
Why Europe Does not Need a Constitution: On the Limits of Constituent Power as a Tool for Democratization
}

\author{
Aliénor Ballangé ${ }^{[0}$ \\ Accepted: 11 October 2021 / Published online: 15 November 2021 \\ (c) The Author(s) 2021
}

\begin{abstract}
In this article, I question the use of the notion of 'constituent power' as a tool for the democratization of the European Union (EU). Rather than seeing the absence of a transnational constituent power as a cause of the EU's 'democratic deficit', I identify it as an opportunity for unfettered democratic participation. Against the reification of power-in-action into a power-constituted-in-law, I argue that the democratization of the EU can only be achieved through the multiplication of 'constituent moments'. I begin by deconstructing the normative justifications surrounding the concept of constituent power. Here I analyze the structural aporia of constituent power and question the autonomous and emancipatory dimension of this notion. I then test the theoretical hypothesis of this structural aporia of the popular constituent power by comparing it with the historical experiments of a European popular constituent power. Finally, based on these theoretical and empirical observations, I propose to replace the ambivalence of the concept of popular constituent power with a more cautious approach to the bottom-up democratization of European integration: that of a multiplication of transnational constituent moments.
\end{abstract}

Keywords European Union · Democratization · Constitution · Constituent power · Constituent moments

\section{Introduction}

Since the American and French Revolutions, it has been generally accepted that democracy, understood as a political regime and system of representation, is inseparable from a constitutional order (see Wolin 2016, pp. 77-78). This constitutional order is based on norms, principles and values - foremost among which are individual liberty and equality-which apply to all citizens present on a given territory. Basically, the disembodied sovereignty of the constitution is opposed to the

Aliénor Ballangé

alienor.ballange@sciencespo.fr

1 Justitia Centre for Advanced Studies, University of Frankfurt-am-Main, Frankfurt, Germany 
arbitrary sovereignty of the Prince based on a contractualist model: sovereignty is no longer understood only as 'the highest power of command' (Bodin 1992, p. 1) but also as the recognition of a right to co-found the laws to which one is subject (Kalyvas 2005, pp. 224-225). The constitutional order allows legal subjects to be equally and simultaneously (recognized as) legal subjects. In democracy, these subjects of law/subjects of right are embodied by the body of citizens that constitutes 'the people'. Thus, if the constitutional model does not specify a priori the type of constituent power that should underlie the constitution, the democratic constitutional order is assumed to be based on a popular constituent power: the people subject to the laws must be their authors (Rousseau 2012, p. 74). Once the constitution is founded by the people, the authority and will of the constituent power are dissolved into a constituted power supposed to guarantee and safeguard the achievements of the constitution.

This storytelling of the democratic constitutional cycle (see Patberg 2018) goes back to Sieyès and has come down to us today without much questioning. In fact, this model is based on a simple and, on the surface, robust argument: in a democracy, the constitution is the supreme sovereign insofar as it embodies the general will of the people united in constituent power. Does this mean that without constituent power there can be no democracy?

This question has been of interest to European political theory for at least 20 years (Crum 2012; Glencross 2014; Nicolaïdis 2004; Niesen 2017; Patberg 2017; Walker 2007; Wolkenstein 2020). If the challenge of a 'European constitution' based on a 'European constituent power' goes back to the very origins of the European project, two events give these discussions a particularly contemporary resonance: the missed opportunity of the 2005 constitutional process and the financial and economic crisis of 2008-2010 (Patberg 2018, p. 272). In the first case, the idea of the constitutionalization of European integration was rather oriented and justified as a protective measure vis-à-vis the outside world: only an effective and legitimate European constitution could defend and preserve the democratic achievements of the member states (MSs) of the European Union (EU) in the face of the growing challenges of globalization (Fischer 2000; Habermas 2001). On the contrary, for most critics of the constitutional process, the draft European constitution was a 'Trojan horse' of globalized neoliberalism (Dardot and Laval 2009): far from protecting national democracies, it would weaken them.

This debate on the constitutional future of the EU took a new turn during the economic and financial crisis of 2008-2010. Faced with austerity policies and the concomitant rise in power of the EU's primary diplomatic (European Council) and economic (European Central Bank) bodies, the idea of the constitutionalization of European integration was oriented toward the EU's interior itself, as a measure to protect one part of Europeans-especially the most precarious citizens-against another-national governments, lobbies, technocrats and unelected experts (Balibar 2016; Habermas 2012; Negri and Cedillo 2015). Conversely, the critics of this new wave of Euro-constitutionalist discourse consider that the interests of European citizens are better represented by their government (in the internal order) and by a myriad of independent expert bodies (in the supranational order) than by a European executive unduly reinforced by a constitution (Majone 2005; Moravcsik 2006). In 
both cases therefore we see an idealist/normative and a skeptical/realist approach to Euro-constitutionalism.

In reality, this opposition between normative and realistic approaches to European integration conceals, in my opinion, more subtle cleavages. First, the controversy is less about the why and the whether of European constitutionalization than about the how (Walker 2007): most realists agree that the EU has gradually equipped itself with all the sufficient tools of a material constitution, ${ }^{1}$ while normative theorists consider that this technical constitution remains insufficient, or even that it was made at the expense of a formal political constitution. It is therefore less a question of asking whether there is a need for a constitution for Europe than of asking what kind of constitution Europe needs.

Secondly, the controversy between realistic and normative theorists is about the who of the constitutionalization of the EU: if the former consider that the constituent power of the material constitution of the EU should remain the work of independent technicians - and notably of jurists - the latter consider that only a popular constituent power is likely to found and legitimize the formal or informal political constitution of the EU. If the need for this European popular constituent power seems little questioned among the defenders of the normative approach, the controversy around the who is significant.

In the wake of debates around the 'borders of demos' (Abizadeh 2012), European normative theory is divided into three main families regarding what can or should be the constituent power of a democratic Europe (Patberg 2018). The first family mobilizes a symbolic approach to constituent power that is embodied in a 'We, the People of Europe'; a 'We' that transcends the cultural and sociological identities of Europeans, coming together in the founding act of a transnational democracy (Balibar 2004; Habermas 2001). The second family mobilizes a pragmatic approach to constituent power, embodied in a 'We, the Peoples of Europe'; a 'We' that intends to give rights to the multiple identities of the 'demoi' of Europe without claiming to sacrifice the pluralism of Europeans on the altar of essentialist symbolism (Besson 2006; Bohman 2007; Cheneval et al. 2015; Nicolaiidis 2004). The third family mobilizes a mixed approach to constituent power that is embodied in a 'We, the Citizens of Europe and of its Member States'; a 'We' that recognizes the double personae of European constituent power, both and simultaneously constituted by national citizens and community citizens (Habermas 2012, 2015, 2017; see Patberg 2017).

As stimulating as they are, these approaches are too quick to bypass two fundamental theoretical and empirical issues: first, they overestimate the link, insufficiently questioned since the transatlantic Revolutions, between the political constitution, popular constituent power and democracy. On this point, radical theories of democracy (Frank 2010; Negri 1999; Rancière 2005; Wolin 2016, pp. 77-99) are useful in tempering the constructivist enthusiasm (Walker 2007, p. 261) of

\footnotetext{
1 Although a constitutional formalization of Europe has failed twice in the history of its integration ('Spinelli' Project in 1984 and Treaty establishing a Constitution for Europe (TECE) in 2005), many scholars today agree on the 'material' constitutionalization of the EU (Mezzadra 2013; Laffaille 2012; Ponzano 2011, p. 99).
} 
European normative theory. Second, by overestimating this connection and focusing almost exclusively on the need to uncover popular constituent power, European normative theory underestimates the immense challenge of revealing or forging popular constituent power without reifying the people for strategic purposes of political constitution-making.

My article proposes to analyze each of these aspects while taking a firm stand on the side of the normative approach, which sees the democratization of the EU as a crucial issue for its survival. I will, therefore, not take up the realistic arguments according to which (a) European democracy in its current state is sufficient in view of the Community constitutional design and the concrete objectives of European integration, (b) only the MS alone can be considered as the legitimate constituent power of the EU because they remain the 'masters of treaties' in the last instance, and (c) the political, social and economic interests of European citizens are better protected in the national internal order than in the supranational order since the internal order (re)distributes places and shares when the supranational order regulates norms (Majone 1996).

My approach consists in bringing a critical theoretical dimension to European normative theory by focusing on the conditions of the production of European popular constituent power through an analysis of the practical consequences of the constituent theories. The objective of this contribution is thus to show (a) that the internal contradictions of the concept of popular constituent power lead to a devitalization of the people as the founding subject of the democratic constitutional order, and (b) that from there, it is appropriate to replace the quest for uncovering or revealing a European popular constituent power with a democratization of the EU order based on transnational 'constituent moments' (Frank 2010).

By 'constituent moment' I do not mean a clearly_and usually institutionallytime-bound period in which a constituent process is initiated, which only ends with the establishment of a (new) constitutional order, based on a formal constitution. In that conception, the 'constituent moment' refers to an exceptional period, a transitional period that is neither intended to last in time nor, above all, intended to be repeated outside the constituent process. Significantly, in this case one speaks of $a$ constituent moment in the singular. Rather I think we must pluralise the notion of the constituent moment. I will argue that constituent moments can, and in my opinion must, exist and be repeated outside the constituent process itself. These constituent moments articulate different registers of claim, including insurgency and vigilance, to allow a plebeian democracy (Breaugh 2013) based on citizenship-inaction, to supplement—not replace - a procedural and representative democracy based only on a citizenship-as-status.

In this article, I focus on the case of the EU to show how the multiplication of constituent moments can revitalize European democracy. Firstly, they make manifest a transnational political culture that proceeds at the level of its citizens. Secondly, they include a part of the European population that excludes itself (through abstention) and/or feels excluded from the European decision-making process. In this context, 'constituent moments' will be understood as ephemeral and repeated manifestations of plebeian insurgency intended to perpetually amend and perfect the European political space outside the formal constituent process. 
In terms of argumentative structure, this paper has a critical and a positive component. The critical component proceeds by way of a critique of conventional European constitutional doctrine. The positive component points to and discusses the promise of constituent moments to continually reinforce the EU transnational democracy from below. The general argument of the paper is structured in five parts. In 'The Conceptual Aporia of Constituent Power: Deconstructing the Link Between Constitution, Constituent Power and Democracy' section, I analyze theoretically the conceptual aporia of constituent power. Then, in 'The Historic Failure of the Projects Establishing a European People's Constituent Power: From the Constituent People to the 'Propaganda Medium' section, I expose the normative consequences of this conceptual aporia, based on the first historical experiments aimed at founding a European popular constituent power. In 'How to Democratize the EU Without Constitution or Constituent Power? The 'Constituent Moments' Argument' section, I suggest that the multiplication of transnational constituent moments, more than the uncovering of a postnational constituent power, is the best way to democratize European integration. Firstly, these constituent moments appear as spaces of education and experimentation for a pluralist democratic culture. Secondly, they give the opportunity to those who exclude themselves or feel excluded from the European decision-making process to express their opinion. Finally, in 'Conclusion' section, I conclude with some prospective questions concerning the probability that the experimentation of citizens' panels organized in the framework of the Conference for the Future of Europe in fall 2021 will represent a sufficiently democratic and popular constitutive moment to reinforce the process of European integration from below.

\section{The Conceptual Aporia of Constituent Power: Deconstructing the Link Between Constitution, Constituent Power and Democracy}

Convinced that the material constitution of Europe expropriates the sovereignty of the 'national-social state' (Balibar 2004) without providing for a popular counterpart, some researchers and activists consider that it is necessary to break with an illegitimate process of constitutionalization by opposing it with a democratic and bottom-up counter-constitution. Thus the DiEM25 manifesto (2016) calls for the creation of a 'democratic pan-European constitution' that would 'replace all the existing European treaties' in order to transform 'a Europe of "We the governments" and "We the technocrats" into a Europe of "We the peoples of Europe". This alterconstitutionalism resonates with Habermas when he writes that 'European citizens [...] have an interest in forming a supranational polity [which would take the frame of a constitution] capable of acting effectively in a democratically legitimate way to solve the problems currently weighing upon the European peoples' (Habermas 2015 , p. 553). However, is passage through the constitution necessary to democratically constitute Europe? Is it even desirable?

Counter-intuitively, Negri writes that 'The constitution is the absolute obstacle to constituent power, to democracy' (Negri 1999, p. 137). What does this mean, and how does this formula alert us to the potential abuses of a democratic constitutionalization of the Union? To develop his hypothesis, Negri starts from the work of 
the British philosopher James Harrington. In Oceania (1977 [1656]), Harrington defends the idea of a constitutional order within which a right to resistance would be provided for and protected. Concretely, the constitution would recognize the power constituting it as 'counterpower' (Negri, p. 117). For Harrington, 'by acquiring its materialist character', constituent power would become 'a machine that constructs social and juridical relations, and [...] a motor for stirring both horizons continually' (Negri, p. 126). But, asks Negri, is giving constituent power a materialist character not already betraying it by freezing it in the time and space of a constitution? As a counter-power, the constituent principle necessarily stands next to power. By taking power-and giving it the force of law-the constituent power becomes power, and thus limits the disruptive and transformative scope of democracy. For the Italian philosopher, democracy must therefore resist any form of constitutional incorporation in order to preserve 'latency of a very strong potential of destruction, and at the same time of transformation of the present state of things' (p. 136).

This position certainly defends a vision of democracy that is at the same time partial, 'absolute' and 'savage' (p. 137). But it has the merit of enlightening us on the limits that could weigh on a constitutionalization of European democratic power. From the moment that the immanent irruption of counter-powers, united in the event of spontaneous resistance to a programed disappropriation of popular sovereignty, informs itself in a transcendent authority - whether embodied in a state or a constitution-it is to be feared that the democratic alternative will be reduced to a simple constitutional alternation. Against this devitalization of democratic power, it would then be a question of considering a constituer that remains forever in action, that is, forever outside the law. Continuing to constitute Europe democratically without any constitution-even a democratic one-would be the task of a radically democratic constituent strategy. Before addressing this issue, I propose to define what a European constituent power can be by drawing on Habermas's most recent work on the double personae of the European political subject (Habermas 2012, 2015, 2017; see Patberg 2017).

For Habermas, constituent power is not inferior to its materialization in the constitutional act. More a political actor than a legal author, constituent power is what sustains the information of living together. Symmetrically, European constituent power corresponds to what, by what, by whom, community integration has come about. As such, European constituent power refers only to the set of forces that participated in the founding of the EU. Moreover, the European constituent power on this conception should be distinguished by its dual quality. It is divided between, on the one hand, the citizens of the Union and, on the other hand, the European peoples (Habermas 2017, p. 175). Therefore, on this view, European constituent power is both purely original as it concerns European citizens and derived from national constituent power as it concerns the peoples of Europe. The dual character of European constituent power is not temporary, since it does not refer to an alternation between the action of European citizens and that of national peoples, but rather synthetic: European constituent power is always and at the same time European and national.

Although stimulating, this hypothesis raises two problems I would like to discuss here: first, are not the 'national peoples' to whom Habermas attributes, in part, the role of European constituent power more constituted than constituent powers? Can 
a power, or a body, already constituted at the national level play the role of a constituent power at the higher European level, or does its constitutional fixation as a sovereign national people prevent it from occupying the function of counter-power that belongs - at least according to Negri-to the constituent power? If, as Sieyès described it, constituent power disappears once the constituent operation is completed, what remains of the 'constituent' role of national peoples once their constitutions are founded? Second, with regard now to the role played by the 'future citizens of the Union', can we see in statutory citizenship a sufficiently robust medium to gather the European multitudes into an effective constituent power? Let us recall that European citizenship is not the result of a contract between European residents-who would claim an 'extension' and a 'denaturalization' of rights (Lacroix 2009) - and the Community institutions, but of a status instituted and granted 'from above', at the time of the ratification of the Maastricht Treaty (1992). Thus, as with national peoples, the very category of 'European citizens' corresponds more to the definition of constituted power than it allows us to glimpse any constituent power. In short, either the feeling of citizenship is not sufficient to mobilize the European multitudes into a 'constituent power', or the status of citizenship reduces the subversive character of the constituent principle to a simple right to act recognized and 'constituted' by European law. Under these conditions, the European constituent power to which Habermas refers seems more to complement the existing power and reproduce the existing state of affairs (Wolkenstein 2020, p. 130; Von Achenbach 2017, p. 196) than to transform it in view of a 'new beginning' for a 'different Europe'.

These few reflections on the situation of European constituent power are significant for what I propose to call the conceptual aporia of constituent power. If most studies deal with the endorsement of constituent power-is this power likely or unlikely to give rise to a political constitution?-few ask about the upstream part of the constituent process. Now, assuming that a notion such as constituent power refers to an empirical reality, it seems necessary to examine the conditions of the emergence of constituent power. Who constitutes constituent power?

First, it must be recognized that constituent power designates an abstract political entity born of a centripetal concentration of multitudes of agents: if we can have the illusion that individual agents are one, it is because their assembly reflects the image of a densely connected conglomerate. But does such an assemblage exist on a human scale? Certainly the answer is yes, when it concerns links of biological necessity (such as the family), but it seems less obvious when we observe the intersubjective links that unite the polis on a free and voluntary basis. Either we consider that in exceptional periods a political ecosystem can emerge spontaneously from a collective awareness that it is necessary to act in this way in order to conserve itself. Or one considers that political practice makes a radical break with nature by replacing necessity with freedom and spontaneity with will, and then one is justified in thinking that any reduction of the multiple to the one must have been provoked, instituted or sought. In this sense, constituent power would only exist as long as it was instituted by a superior principle or force (Arato 2016, pp. 1-15).

It is therefore not only a question of looking at the modalities of emergence of the constituent community, but also of asking whether this constituent force did not lose its subversive power as soon as it was constituted. From the moment that the 
constituent power gathers together by resembling itself-so much so that it appears as one-its revolutionary scope tends, in fact, to boil down to the establishment of a new constitutional identity: the constituent power only exists as it is recognized and identified as such. It then refers less to the transforming force of an active power than to the subject - unified, organized, visible — of action. And precisely, any attempt to 'build the people' for pragmatic and utilitarian purposes-including the 'radicalization of democracy' (Mouffe and Errejón 2017)—seems to me questionable when it denies the 'savage' and spontaneous element that animates any truly democratic constituent event. Rather, in my view, the fundamental issue at stake consists in asking how the emancipatory process contained in the constituent moment can resist its dissolution in a heteronomously instituted constituent power. I will develop this idea further in 'How to Democratize the EU Without Constitution or Constituent Power? The 'Constituent Moments' Argument' section.

In 'The Conceptual Aporia of Constituent Power: Deconstructing the Link Between Constitution, Constituent Power and Democracy' section, I have tried to present some of the ambiguities and contradictions that weigh on the concept of constituent power. Starting from a theoretical analysis, I showed in particular that constituent power is necessarily a power already constituted by a heteronomous entity that aims to reduce the multitude of the people to a political power capable of action. In the following section, I intend to confront this theoretical analysis with the historical empirical reality of European integration by looking at the first experiments with a European popular constituent power. Using three archival documents - a draft European constitution dating from 1944 and two of the first forums that attempted to establish a European popular constituent power-I will show how the people united in constituent power can also become a 'propaganda medium' for the defenders of the constituent strategy.

\section{The Historic Failure of the Projects Establishing a European People's Constituent Power: From the Constituent People to the 'Propaganda Medium'}

In a recent article, Wolkenstein (2020) proposes to adapt the concept of constituent power to the specific framework of European integration by adopting a suprastate approach. Specifically, he proposes to further exploit the notion of 'transnational partisanship' in order to understand how the transnational coordination of ideologically constituted networks at the national level can gradually participate in the constitution of a transnational constituent power sufficiently homogeneous and coherent to allow all of its supporters to identify common interests beyond the state and national scale. To illustrate his thesis, Wolkenstein takes the example of Christian Democracy, a transnational network that would have managed, in the 1950s, to influence the construction of Europe by organizing a set of national movements and parties, the majority of which came from the Christian-inspired centre-right.

This approach is interesting because it gives depth to contemporary theoretical debates on the foundation of a European constituent power. However, it poses several problems. First, Wolkenstein presupposes a constituent vocation to a network 
that has never claimed to present itself as any kind of European constituent power. If this network shared a common vision of Europe and if it was able to have constituent effects, prudence obliges us to guard against any retrospective teleology that would attribute to a past network considerations that were foreign to it at the time. Secondly, as Wolkenstein acknowledges, the Christian-democratic network can hardly serve as a model for thinking about a popular constituent power insofar as (a) it was itself composed of personalities coming almost exclusively from the national political, economic and cultural elites, and (b) it was at no time addressed to the people of Europe, but only to the most influential personalities of the community order. Thus, rather than studying the heuristic potential of transnational partisanship in terms of an elite movement devoid of an explicit constituent discourse, I propose to start from Wolkenstein's initial argument by rereading it in the light of the first federalist experiments with a 'European constitution' and popular forums with a constituent vocation.

Beginning with Ventotene's Manifesto (Rossi and Spinelli 1941), the Italian Resistance differs from other federalist movements in that it places the 'people' at the center of the process of European integration (Vayssière 2006). In search of genuine autonomy from national political parties and leaders, the federalist movement campaigned for a constitutional Europe, legitimized by its peoples and ratified by all 'European citizens'. From the very first drafts of the European constitution, drawn up during the Resistance, the people appeared as a major figure in federalist political integration. However, as revolutionary federalists such as Altiero Spinelli and Mario Albertini pointed out, the people only became truly a public actor when they 'became aware of themselves' (Spinelli 1956, p. 9). This means, first, by using the performative discourse of the constitutional project to construct the myth of transnational unity and, second, by politically founding the European people in constituent power. One document stands out from the other political booklets published by the Italian Resistance fighters in the early 1940s. The 'Schema di constituzione dell'Unione Federale Europea', 5000 copies of which were distributed in January 1944, was the second draft constitution written by an Italian intellectual. ${ }^{2}$ Its author, Mario Alberto Rollier, was a close associate of Spinelli and co-founded the Movimento Federale Europeo. This draft constitution is particularly interesting for its preamble:

We, the peoples of the Federal Union [Noi, popoli dell'Unione Federale], in order [...] to perpetuate the government of the people, by the people, for the people [il governo del popolo, per il popolo attraverso il popolo], in the name of the right of everyone to participate in the government of all, let us establish and promulgate this Constitution of the European Federal Union. ${ }^{3}$

\footnotetext{
2 The first is the 'Progretto di constituzione confederale europea ad interna' written by Tancredi Galimberti and Antonio Repaci in April 1943.

3 Mario Alberto Rollier, 'Schema di constituzione dell'Unione Federale Europea', 1944. This document is transcribed in Walter Lipgens (1985, p. 528). My translation.
} 
Modeled on the preamble of the Constitution of the United States of America, this text has the originality of pluralizing the subject of the Constitution, namely 'we', the union of the 'peoples' of Europe [Noi, popoli dell'Unione Federale]. If the expression 'we [...] establish and promulgate [...]' actualizes and presents a common subject, it does not reduce the European multiple in the regime of the singular 'we'. What is more, something of a disidentification of the 'people' from the national collective seems to emerge from a careful reading of this preamble. Indeed, if the first 'we' is pluralized by the various 'peoples of the Federal Union', the allusion to Lincoln's famous formula preserves the singular character of this 'type' of people. Thus, if the 'we' refers to the national and cultural peoples of a plurinational Europe, the 'people' of European democracy ('the government of the people, by the people, for the people') designates a singular entity that brings together citizens united by the same civic conscience, beyond the borders of the nation-state. Now let us see how this call for a democratic constitution of Europe has been translated into the constitution of ephemeral transnational forums designed to bring together the peoples of Europe in European constituent power.

Following the failure of the European Defence Community project (1954) which also contained a draft constitutional project called the European Political Community - Spinelli published a programatic article entitled 'Nuovo corso' in Europa Federata (Spinelli 1954). The struggle for the recognition of the constituent power of the 'European people' was reaffirmed: in the face of the prevarication of national leaders and political parties, the popular constituent power would be the only 'European political force ready to fight with decision, precision and continuity to achieve the goal of federal unity'. In concrete terms, this political program materialized in the 1956 Stresa meeting in the creation of a 'European People's Congress [Congrès du people européen]'. This new body was intended to select on a popular and voluntary basis the delegates of the people who were then supposed to meet in an unofficial and transnational Constituent Assembly. Underlying this, the Congrès presented itself as the connecting organ between a European people, supposedly still little aware of itself, and activists in search of legitimacy. Organizationally, the Congrès was a shadow people's assembly - a kind of parliamentary shadow cabinet-inspired by both the American and French Revolutions to bring to life a transparent and transnational representative democracy. The main concrete political results of this transnational forum were the adoption of the 'Manifesto of the European Federalists' (1957), the establishment of election campaigns open to all European citizens wishing to become involved in the federalist project, ${ }^{4}$ the election of people's delegates to precipitate the convocation of an Assembly elected by direct universal suffrage that would meet as soon as possible to establish a European

\footnotetext{
4 The first electoral campaign organized to select the members of the Congrès began on 6 September, 1957 in Antwerp. In the end, more than 640,000 voters turned out for the 1960 congressional election campaign. This would make Luciano Bolis, a militant of the European Federalist Movement, say that the experience of the Congrès was a rehearsal for the election, in 1979, of the very first transnational Parliament elected by direct universal suffrage.
} 
federal constitution, and the exploitation of 'Cahiers de revendications' based on the demands of the 'European people'.

As the experience of the Congrès gradually lost its vigor in the early 1960s, Albertini decided to create a new popular body in order to (re)mobilize European public opinion. Launched in 1964, the 'Voluntary Census of the European Federal People for the Recognition of its Constituent Power [Le Recensement volontaire du onsti onstit européen]' was to enable the people to 'effectively express their European feeling and affirm it by force of numbers ${ }^{5}$. The Census was intended to broaden the audience of the People's Congrès so that federalist sentiment could go beyond the confines of the institution and reaches out to 'weak groups [onsti faibles]' and even 'isolated individuals' who in turn could build new action groups throughout Europe. Extremely precise in its method, the Census presented itself as a 'cash register [caisse enregistreuse]' of citizens' declarations in favor of European integration. The objective was to 'move from private European feeling to public European feeling, in other words to the first degree of political strength'. This body, it was hoped, would make it possible to measure the euro-enthusiasm of a public that is not very audible, while at the same time giving it a positive image with regards to its commitment to the European federation, 'so that by attributing its full European identity to it, [the people] no longer feel a passive element in the construction of Europe'. Against the vertical integration of the functionalist approach, Albertini defended a centrifugal dynamic of federal construction: a hard core of intellectuals would constitute a 'European people' by winning, from 'weak' to 'strong' influence groups, the field of public opinion. To this end, he considered it necessary to mobilize all the expedients capable of 'bringing Europe' closer to its citizens and 'creating an organic link between federalists, the population of the city and its social onsti': among these expedients, 'the distribution of the federalist press (among others, the Journal du Recensement was published), the distribution of badges, car stickers, etc. in order to make European sentiment visible in the city'.

What can we learn from these historical transnational experiments whose explicit objective was to found a European popular constituent power with the aim of democratizing the process of community integration? Firstly, if the expression 'the (European) people' is omnipresent in the manifestos, leaflets, cards and declarations of the federalists, it must be noted that the real people of European citizens paradoxically remained largely in oblivion of these 'popular' transnational experiments. Thus, there is no archive proving, at the time, the effective mobilization of the people in favor of the European federation; it is significant, therefore, that the 'Cahiers de revendication $d u$ onsti' were all written by the militants and elites of the movement. Even in this federalist movement for the 'bottom-up' democratization of European integration, the real people were summoned to support, vote and cheer, but their effective participation in the political agenda remained limited, even in the phase of their self-foundation as constituent power. As Spinelli and Albertini explained, the identification of the people in constituent power must proceed from a heteronomic

\footnotetext{
5 See the anonymous sheet entitled «Le recensement volontaire du peuple fédéral européen», Il Federalista, 1966, 1, 44-50. My translation.
} 
logic from which an enlightened vanguard allows a multitude to become aware of itself and of its political power: 'Enclosed in a [stato-national] prison that prevents it from forming and manifesting its will' (Cabella 1956), the European people would not yet be capable of freeing itself from its old thought pattern; it is therefore a question of preparing its emancipation-however paradoxical a heteronomous emancipation may be.

This heteronomization of constituent power echoes the theoretical observation that I presented in the first part of this essay: if European constituent power is always constituted both historically in the national order and by an enlightened elite on the European scale, what really remains revolutionary and autonomous in constituent power? Second, if constituent power is constituted by an externalized process of identification-multitudes recognize themselves as constituent power through the mediation of visionary intellectuals - how can the danger of a uniformization of constituent power be averted? Since popular constituent power is the image of those who inform it, it is plausible that constituent power will be overwhelmingly pro-European if it is informed by a federalist vanguard (which de facto excludes from popular constituent power all skeptical or critical citizens) or overwhelmingly liberal and progressive if it is informed by 'left-wing' transnational forums (such as DiEM25, for example) or overwhelmingly white and Christian if it is informed by identity movements. Thirdly, as illustrated by the evolution of the Census, there is a great risk that the notion of constituent power will be transformed into public opinion, or even into a simple electoral clientele. Since constituent power, as a symbolic political subject, has no real political autonomy, its role consists essentially in approving or rejecting, when asked to do so, partial measures or, more rarely, a constitutional text-even though in reality it is its representatives who are most often called upon to pronounce on this type of text. The popular constituent power is then only a public whose favors are to be won. As mentioned in Il Federalista's sheet on the Census, an experiment that aimed, I recall, above all to allow the European people to 'recognize their constituent power': 'a large part of the population is for Europe, or easily becomes so if one poses the problem' (my emphasis). And the sheet concludes, not without cynicism, that this is 'perhaps the first time in history that political propaganda is paid for by those for whom it is intended [the people] and not by those who make it [the federalist militants]'.

Faced with these three risks - namely (a) the lack of autonomy of a previously constituted constituent subject, (b) the identification of the constituent subject as a homogeneous whole and (c) the political devitalization of the popular constituent power as an organ of acclamation-which seem both theoretically and empirically intrinsic to the very notion of popular constituent power, I suggest, in the following section, an alternative approach to the democratization of the EU. Precisely, I propose to replace the search for a European popular constituent power with the multiplication of transnational 'constituent moments'. 


\section{How to Democratize the EU Without Constitution or Constituent Power? The 'Constituent Moments' Argument}

In this section, I propose to borrow from the 'fugitive' theory of democracy its guiding hypothesis that 'Democracy [...] seems destined to be a moment rather than a form' (Wolin 1994, p. 19, emphasis added). In this conception, democracy refers less to a social state based on a demand for equality or a form of government based on the representation of a sovereign people than to an event that disrupts the ordinary administrative functioning of government (Kalyvas 2008; Rancière 1998, 2005). Democracy is situated within a tension between constitutional politicswhich has the double vocation of defining/delimiting then preserving/regulatingand revolutionary politics, which upsets the existing order rather than instituting or fixing it. Constitution and democracy cannot, strictly speaking, be seen as working together: 'a constitution in setting limits to politics sets limits as well as to democracy, constituting it in ways compatible with and legitimating of the dominant power groups in the society' (Wolin 1994, p. 14). Wolin gives some examples of democratic 'moments' that (re)constitute commonality without it ever being fixed in a constitution or assumed to be the business of a constituent power encompassing and constituted by others:

Individuals who concert their powers for low income housing, worker ownership of factories, better schools, better health care, safer water, controls over toxic waste disposals, and a thousand other common concerns of ordinary lives are experiencing a democratic moment and contributing to the discovery, care, and tending of a commonality of shared concerns. (Wolin 1994, p. 24)

This 'fugitive' approach to democracy seems to me both transposable to the European framework and necessary in order to understand the democratization potential of certain seemingly sporadic and ephemeral movements. The first European federalists called for building a Europe of the peoples based on a transnationalization, from below, of their struggles and projects during the years of resistance to fascism. Similarly, we can see the experimentation of a network of constituent moments based more on the logic of insurgency than on that of institution or constitution in, for instance, the advent of the anti-austerity movements in the 2010s. Take an example from Spain. Before being a political party, 'podemos' basically means 'we can'. The verbal form remains without object, it does not specify what 'we can' means. It only evokes the power of autonomous political subjects who may sporadically come together to defend common causes.

This demand for a 'pouvoir-constituer' manifested in a series of 'constituent moments' that were not limited to the Spanish national framework. A (timid) transnational resistance can be seen for example in the 'Sol-Syntagma' joint statement. This join statement was launched on 9 September, 2011, by the Indignados de la Puerta del Sol and the strikers of Syntagma Square to coordinate a common European movement of anti-authoritarian struggle. A manifesto for another Europe was drafted on this occasion and a march on Brussels was organized the following year, in 2012. Beyond, or perhaps below, the Sol-Syntagma joint statement, 
which nevertheless retains a programed and organized dimension, a transnationalization, from below, of popular constituent moments has been illustrated in certain demonstrations during which a 'politics of empathy' (Rancière, 1998) has been experimented. Thus, at the beginning of 2010, we could see the multiplication of post-identity slogans during anti-austerity demonstrations. On the demonstrators' billboards, one could read 'We are all Greeks', 'Nous sommes tous des Grecs', 'Siamo tutti Greci', etc.

This networking of demands for recognition (Honneth 1995) is interesting because it provides an empirical link between Habermas and Wolin. Through the sporadic and ephemeral manifestations of an empathy founded in action and for social justice, a constituent moment emerges on the basis of the double personae of constituent power presented by Habermas: as national citizens, each in their own language, it is a matter of saying that 'we' are already and at the same time European citizens-not only in the sense of legal status, but in the sense that 'we' can feel and relay the claims of other European citizens who feel victims of social and political injustice. Rather than constituting themselves, or being translated into a constituent power by an enlightened vanguard, citizens gathered in these insurgent constituent moments proclaim and repeat as many times as they consider necessary a right to have rights' (Arendt 1958, pp. 290-302; Lefort 1988, p. 37) that extends beyond the fixed and rigid framework of a constitution. Where constitutional democracy may be accused of being moulded into a Procrustean bed (Waldron 1999, p. 268) that defines citizens' rights from above and below, an insurgent democracy that rests on an unlimited series of constituent moments has the double merit of pointing out that in a democracy citizens permanently retain the right - that is, the authorization they have given themselves - to claim or to have recognized (new) rights through a democratic perfectionism that does not end with the codification of a constitutional text.

Now, if we look back to the experiences of popular constituent moments that emerged in the EU in the 2010s through spontaneous and insurgent protests, we see that the argument for democratizing the EU through the multiplication of constituent moments also has at least two concrete empirical advantages. First, as Jason Frank demonstrates in his discussion of the 'micro-societies' of the DemocraticRepublican Societies of the 1790s, which provided a bottom-up education in democratic agonistic practices (2010, p. 130), the anti-austerity movements too constitute forums of political education that took on a European dimension as transnational convergence was attempted. Secondly, the insurgent democracy that manifested in these constituent moments had the advantage of giving a voice to all citizens of Europe, even beyond European citizens. Indeed, there is no need to be a citizen of a European nation-state to express oneself in these spontaneous, ephemeral citizens' assemblies, which are not organized by any institutional referents. The degree of inclusiveness encountered during constituent moments is therefore necessarily higher than that of a 'constituent power' that would only be composed of 'already' European citizens whose vocation is to enact a European Constitution whose norms, principles and values extend to all individuals living in the EU. 


\section{Conclusion}

The objective of this paper was both to (a) advance an internal critique of a part of European normative political theory, taking as a case study its defense of popular constituent power as the privileged medium of democratization of the EU, and (b) to propose an alternative approach of democratization from below of European integration. First, I have tried to confront the constructivist optimism of normative theory with the dialectical vigilance of critical theory by looking at the conditions of production of the normative discourse in favor of the constituent process and the practical consequences of this discourse on its object of analysis.

Second, I have tried to show that a European popular constituent power was neither necessary nor even desirable for democratizing European integration. In order to achieve this double objective, I began by deconstructing the normative justifications surrounding the concept of constituent power. I uncovered the structural aporia of constituent power, which could be summarized as follows: any constituent power must have been previously constituted by a heteronomous instance in order to claim the status of autonomous political subject. Thus, there is no, strictly speaking, popular constituent power, but only constituted powers with a constituent vocation. In the second part of the article, I have tested the theoretical hypothesis of this structural aporia of the popular constituent power by comparing it with the historical experiments of a European popular constituent power. In particular, I was interested in the first drafts of the European democratic constitution and in the democratic federalist forums of the 'Congrès du people européen' and the 'Recensement volontaire $d u$ onsti onstit européen pour la reconnaissance de son pouvoir onstituent'. This retrospective study has enabled me to show that no European constituent people can constitute itself by and for itself without first having been constituted for strategic purposes. Thus, the foundation of popular constituent power necessarily seems to remain heteronomous to the people and the democratic character of the constitutional cycle appears, to say the least, ambiguous.

Elaborating on this critical perspective, I proposed an alternative model of EU democratization based on the actualization of an insurgent citizenship that manifests itself in an ephemeral manner during 'constituent moments'. These sporadic popular manifestations appear to be constitutive insofar as they have the vocation to continuously reinterrogate and perfect the principles, values and norms of the EU, where popular constituent power loses its effective sovereignty once the constitutive process is completed. Not only do the micro-societies constituted during the "constituent moments' experience, in a tangible and concrete way, a form of education to transnational citizenship, but they also give voice to individuals who would be excluded from an institutionalized constituent process.

However, as political theorists, we cannot overlook the fact that these constituent moments are by definition sporadic and unpredictable, and we cannot rely solely on 
these manifestations of citizen insurgency to revitalize European democracy. Perhaps then, we should broaden our definition of 'constituent moments' to include democratic experiments whose deliberative character has been previously organized by an institutional procedure. Here I am referring to the citizens' panels organized in the fall of 2021 within the very formal framework of the Conference on the Future of Europe. Concretely, four panels, each bringing together 200 European citizens selected at random deliberate during three three-day sessions on themes such as social justice, the European rule of law, EU values, climate change, immigration and Europe's place in the world. According to the official terms used in the 'Note to the attention of the Executive Board', the aim is to 'leave enough room for a true bottom up and citizens-driven deliberation'. ${ }^{6}$

This experimentation with a deliberative assembly organized on a supranational scale raises many questions even as it arouses the interest of EU political theorists. On the one hand, the spontaneous and insurgent dimension of our definition of 'constituent moments' is largely minimized by the fact that the organization of these assemblies is completely independent of the citizens who will deliberate in them. Second, the fact that the participants are all European citizens, and therefore nationals of member states, limits the inclusiveness of the mechanism by leaving out all non-European nationals who are nevertheless subject to European laws. Thirdly, if these participants were initially selected at random, they were then contacted by phone and left free to participate or not in this event. It is therefore likely that only those who felt most competent and/or most concerned about European integration agreed to participate. While our approach to constituent moments is based on the fact that spontaneous citizen demonstrations give voice to those excluded from the decision-making process, there is a risk that the CoFoE deliberative assemblies only give voice to those who are already using their voice to defend or call for the dismantling of the EU.

On the other hand, there are still reasons to be optimistic about the world's first experiment of a deliberative assembly organized on a transnational scale. First, the relatively flexible organization of these assemblies does not a priori prevent an unforeseen form of insurgency from arising from the citizens themselves on the occasion of an issue sufficiently mobilizing for a pluri-ideological and pluri-national micro-society to be self-constituted during, or even after, the CoFoE. Second, one of the positive consequences I identified regarding the insurgent logic of constituent moments referred to the idea of a pragmatic education in democratic culture. Even if the citizens' panels are not followed by any concrete effect on the European decision-making process, the mere fact that four groups of 200 citizens from 27 different countries were brought together three times over nine days should be recognized as part of an important process of democratic transnational socialization.

Acknowledgements I warmly thank the two anonymous reviewers for their valuable comments. I also thank Gordon Arlen for his proofreading and his helpful advice. This research has been supported by the Alfons and Gertrud Kassel Foundation through the Justitia Center for Advanced Studies (Goethe University Frankfurt).

\footnotetext{
${ }^{6}$ Conference on the Future of Europe, 'Note to the attention of the executive board: Update of the practical modalities of the European citizens' panels': https://assets.futureu.europa.eu/uploads/decidim/attac hment/file/26336/European-Citizens-Panels-Updated-practical-modalities.pdf.
} 
Funding Open Access funding enabled and organized by Projekt DEAL.

Open Access This article is licensed under a Creative Commons Attribution 4.0 International License, which permits use, sharing, adaptation, distribution and reproduction in any medium or format, as long as you give appropriate credit to the original author(s) and the source, provide a link to the Creative Commons licence, and indicate if changes were made. The images or other third party material in this article are included in the article's Creative Commons licence, unless indicated otherwise in a credit line to the material. If material is not included in the article's Creative Commons licence and your intended use is not permitted by statutory regulation or exceeds the permitted use, you will need to obtain permission directly from the copyright holder. To view a copy of this licence, visit http://creativecommons.org/licen ses/by/4.0/.

\section{References}

Abizadeh, Arash. 2012. On the demos and its kin: Nationalism, democracy, and the boundary problem. American Political Science Review 106 (4): 867-882.

Arato, Andrew. 2016. Post sovereign constitution making: Learning and legitimacy. Oxford: Oxford University Press.

Arendt, Hannah. 1958. The origins of totalitarianism. Cleveland, OH: World.

Balibar, Étienne. 2004. We, the people of Europe? Reflections on transnational citizenship. Princeton, NJ: Princeton University Press.

Balibar, Étienne. 2016. Europe, crise et fin? Lormont: Le Bord de l'eau.

Besson, Samantha. 2006. Deliberative Demoi-cracy in the European Union: Towards the deterritorialization of democracy. In Deliberative democracy and its discontents, ed. Samantha Besson and José Luis. Martí, 181-214. Aldershot: Ashgate.

Bodin, J. 1992. On sovereignty. Cambridge: Cambridge University Press.

Bohman, James. 2007. Democracy across borders: From Dêmos to Dêmoi. Cambridge, MA: MIT Press.

Breaugh, Martin. 2013. The plebeian experience: A discontinuous history of political freedom. New York: Columbia University Press.

Cabella, Alberto. 1956. Lettre $\mathrm{n}^{\circ} 2$ « Aux membres du Comité d'Initiative de la lutte pour le peuple européen ». Fonds d'archives André Darteil, Historical Archives of the European Union, Florence.

Cheneval, Francis, Sandra Lavenex, and Frank Schimmelfennig. 2015. Demoi-cracy in the European Union: Principles, institutions, policies. Journal of European Public Policy 22 (1): 1-18.

Crum, Ben. 2012. Learning from the EU constitutional treaty: Democratic constitutionalization beyond the nation-state. New York: Routledge.

Dardot, Pierre, and Christian Laval. 2009. La nouvelle raison du monde: Essai sur la société néolibérale. Paris: La Découverte.

DiEM25. 2016. A manifesto for democratising Europe. http://diem25.org/wp-content/uploads/2016/02/ diem25_english_long.pdf.

Fischer, Joschka. 2000. From confederacy to federation-Thoughts on the finality of European integration. Speech at the Humboldt University in Berlin 12/05/2000. Available at: https://www.cvce.eu

Frank, Jason A. 2010. Constituent moments: Enacting the people in postrevolutionary America. Durham, NC: Duke University Press.

Glencross, Andrew. 2014. The absence of political constitutionalism in the EU: Three models for enhancing constitutional agency. Journal of European Public Policy 21 (8): 1163-1180.

Habermas, Jürgen. 2001. Why Europe needs a constitution. New Left Review 11: 5-26.

Habermas, Jürgen. 2012. The crisis of the European Union: A response. Cambridge: Polity.

Habermas, Jürgen. 2015. Democracy in Europe: Why the development of the EU into a transnational democracy is necessary and how it is possible. European Law Journal 21 (4): 546-557.

Habermas, Jürgen. 2017. Citizen and state equality in a supranational political community: Degressive proportionality and the pouvoir constituant mixte. Journal of Common Market Studies 55 (2): 171-182.

Harrington, James. 1977. The political works of James Harrington. Cambridge: Cambridge University Press. 
Honneth, Axel. 1995. The struggle for recognition: The moral grammar of social conflicts. Cambridge: Polity Press.

Kalyvas, Andreas. 2005. Popular sovereignty, democracy, and the constituent power. Constellations 12 (2): $223-244$.

Kalyvas, Andreas. 2008. Democracy and the politics of the extraordinary: Max Weber, Carl Schmitt, and Hannah Arendt. Cambridge: Cambridge University Press.

Lacroix, Justine. 2009. Une citoyenneté européenne est-elle possible? La Vie des idées, 3 juin 2009.

Laffaille, Franck. 2012. La notion de constitution au sens matériel chez Costantino Mortati. La 'zone grise' du droit constitutionnel. Jus Politicum 7.

Lefort, Claude. 1988. Democracy and political theory. Minneapolis: University of Minnesota Press.

Lipgens, Walter, ed. 1985. Documents on the history of European integration, 1. Berlin, New York: De Gruyter.

Majone, Giandomenico. 1996. Regulating Europe. London: Routledge.

Majone, Giandomenico. 2005. The dilemmas of European integration. Oxford: Oxford University.

Mezzadra, Sandro. 2013. Seizing Europe. Crisis management, constitutional transformations, constituent movements. In Post-crisis perspectives: The common and its power, ed. Oscar Garcia Augustin and Christian Ydesen, 99-118. Frankfurt-am-Main: Peter Lang Verlag.

Moravcsik, Andrew. 2006. 'A category error'. Prospect, July 2006, 22-26.

Mouffe, Chantal, and Iñigo. Errejón. 2017. Construire un peuple: Pour une radicalisation de la démocratie. Paris: Éditions du Cerf.

Negri, Antonio, Raúl Sánchez Cedillo. 2015. For a constituent initiative in Europe. http://transversal.at/ blog/For-a-constituent-initiative-in-Europe.

Negri, Antonio. 1999. Insurgencies: Constituent power and the modern state. Minneapolis: University of Minnesota Press.

Nicolaïdis, Kalypso. 2004. The new constitution as European 'Demoi-cracy'? Critical Review of International Social and Political Philosophy 7 (1): 76-93.

Niesen, Peter. 2017. The 'mixed' constituent legitimacy of the European federation. Journal of Common Market Studies 55 (2): 183-192.

Patberg, Markus. 2017. The levelling up of constituent power in the European Union. Journal of Common Market Studies 55 (2): 203-212.

Patberg, Markus. 2018. Challenging the masters of the treaties: Emerging narratives of constituent power in the European Union. Global Constitutionalism 7 (2): 263-293.

Ponzano, Paolo. 2011. Le processus de constitutionnalisation de 1'Union européenne. In Le pouvoir constituant et l'Europe, ed. Olivier Cayla and Pasquale Pasquino, 99-106. Paris: Dalloz.

Rancière, Jacques. 1998. Aux bords du politique. Paris: Gallimard.

Rancière, Jacques. 2005. La haine de la démocratie. Paris: La Fabrique.

Rossi, Ernesto, Altiero Spinelli. 1941. Le manifeste de Ventotene. http://www.cvce.eu.

Rousseau, Jean-Jacques. 2012. Le contrat social. Paris: GF Flammarion.

Spinelli, Altiero. 1956. Les raisons de notre lutte. In Le congrès du peuple européen. Documents. Fonds d'archives André Darteil, Historical Archives of the European Union, Florence, 3-10.

Spinelli, Altiero. 1954. Nuovo corso. Europe Federata 7 (10): 221-227.

Vayssière, Bertrand. 2006. Vers une Europe fédérale? Les espoirs et les actions fédéralistes au sortir de la Seconde Guerre mondiale. Berlin: PIE-P. Lang.

Von Achenbach, Jelena. 2017. The European Parliament as a forum of national interest? A transnationalist critique of Jürgen Habermas' reconstruction of degressive proportionality. Journal of Common Market Studies 55 (2): 193-202.

Waldron, Jeremy. 1999. Law and disagreement. New York: Oxford University Press.

Walker, Neil. 2007. Post-constituent constitutionalism? The case of the European Union. In The paradoxe of constitutionnalism: Constituent power and constitutional form, ed. Martin Loughlin and Neil Walker, 247-267. Oxford: Oxford University Press.

Wolin, Sheldon S. 1994. Fugitive democracy. Constellations 1 (1): 11-25.

Wolin, Sheldon S. 2016. Fugitive democracy : And other essays, 2017. Princeton, NJ: Princeton University Press.

Wolkenstein, Fabio. 2020. Transnational partisan networks and constituent power in the EU. Constellations 27 (1): 127-142.

Publisher's Note Springer Nature remains neutral with regard to jurisdictional claims in published maps and institutional affiliations. 